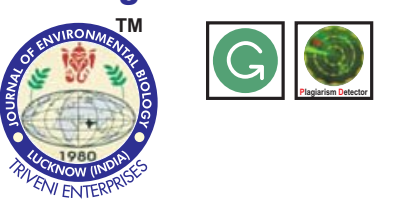

\title{
Soil health assessment under protected cultivation of vegetable crops in North West Himalayas
}

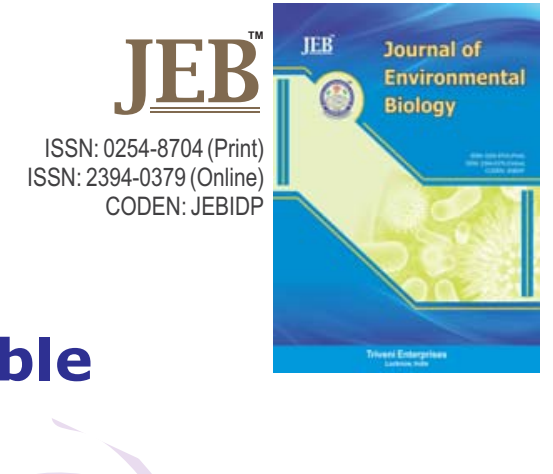

Authors Info

Sumita Chandel ${ }^{1 *}$, D Tripathi ${ }^{2}$ and Ridham Kakar ${ }^{2}$

${ }^{1}$ Department of Soil Science, Punjab Agricultural University, Ludhiana-141 004, India

${ }^{2}$ Department of Soil Science and Water management, Dr. Y. S. Parmar University of Horticulture and Forestry, Nauni,

Solan-173 230, India

*Corresponding Author Email : sumi.chandel@gmail.com

Key words

Polyhouse,

Nutrient status,

Soil health index,

Soil indicators, Sustainability

Publication Info

Paper received : 28.01 .2015

Revised received : 26.02 .2016

Re-revised received : 15.06 .2016

Accepted : 13.07.2016
Abstract

Aim : Soil health is a concept that integrates soil physical, chemical and biological indicators into a framework for soil resource evaluation. Quantitative assessment of soil health is required to determine the sustainability of land use in terms of environmental quality and plant productivity. The main objective of the study was to find out the impact of intensive cultivation on soil health under polyhouses condition of mid hill zone of Himachal Pradesh.

Methodology : The soil samples were collected from polyhouses and adjacent open fields from three districts of Himachal Pradesh, India (Mandi, Solan and Sirmour) and were analysed for physical (bulk density, particle density and porosity), chemical ( $\mathrm{pH}, \mathrm{EC}$, organic carbon, cation exchange capacity, bicarbonate, chloride, available $\mathrm{N}, \mathrm{P}, \mathrm{K}$, extractable calcium, magnesium and SO4-S, DTPA extractable $\mathrm{Zn}, \mathrm{Fe}, \mathrm{Mn}$ and $\mathrm{Cu}$ ) and biological (microbial biomass $\mathrm{C}$ ) properties. All the soil indicators were combined to calculate soil health index (SHI).

Results : The soil health indicators like $E C, O C, P, S$, chloride and microbial biomass had more influence on soil health under polyhouse condition. Majority of the soils in polyhouse conditions were in high soil health (57\%) of the surveyed samples, followed by very high (40\%) and medium health soil (3\%).

Interpretation : Soil health was found to be affected by the management practices adopted by the farmers and the extent of fertilizer used over a period of time.

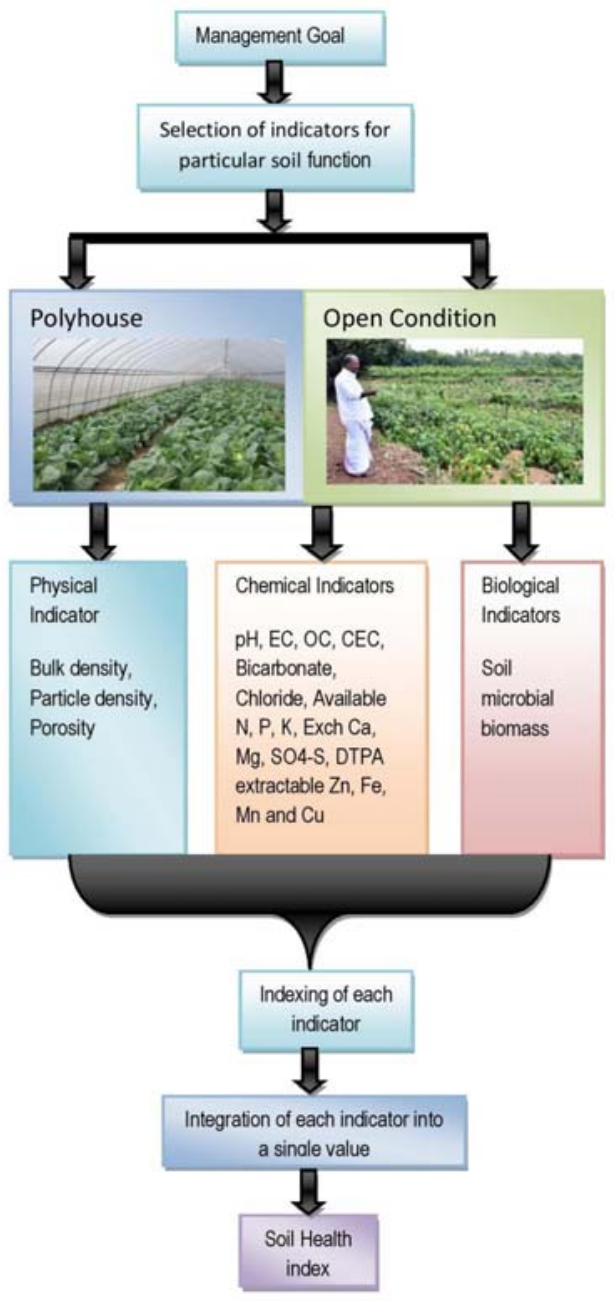




\section{Introduction}

Soil health is a major global issue, which may be defined as a continued capacity of soil to function as a vital living system, by recognizing that it contains biological elements that are key to ecosystem function within land-use boundaries (Doran and Zeiss, 2000; Karlen et al., 2001). The term of soil health is used to assess the ability of a soil to sustain plant and animal productivity and diversity, maintain or enhance water and air quality, and support human health and habitation. Since all agricultural activities are directly or indirectly, affected by how the "soil is handled", its health becomes the prime concern before one can address human and livestock health issues. Managing soils is a formidable challenge to ensure productivity, profitability and national food security. The state of soil health is governed by a number of physical, chemical and biological attributes/ processes. Soil health degradation is posing a major threat to agricultural sustainability and environmental quality. This degradation may be due to improper fertilization, improper tillage operations, monoculture, excessive use of agrochemicals, depletion of soil organic matter, erosion of topsoil etc. (Mandal, 2011). Prevalence of one or more unfavorable soil conditions for long periods leads to unsustainability of agricultural system. Major issues of soil health under Indian context include: physical degradation caused by compaction, crusting, excessive cultivation or puddling, water logging and soil erosion, chemical degradation caused by wide nutrient gap between nutrient demand and supply, high nutrient turn over in soil-plant system coupled with low and imbalanced fertilizer use, emerging deficiencies of secondary and micro nutrients, poor nutrient use efficiency, insufficient input of organic sources because of other competitive uses, acidification and aluminum toxicity in acid soils, salinity and alkalinity, biological degradation due to organic matter depletion and loss of soil fauna and flora, and soil pollution from industrial wastes, excessive use of pesticides and heavy metal contamination. Intensive cultivation, raising more crops from unit area of land, results in a rapid depletion of organic matter content of soil and adversely affects the soil's physical condition causing deterioration in soil aggregation. The lighter soils become more vulnerable to erosion by wind and water which gives rise to loss of top soil and aggravates the problem of landscape degradation. In spite of increase in fertilizer consumption and low response, the soil health is continuously deteriorating due to imbalanced fertilizer use coupled with low use of organic manures. The soils are not being adequately replenished even for the macronutrients, let alone the secondary and micronutrients. The improper nutrient management has, therefore, led to emergence of multi-nutrient deficiencies in the Indian soils. The basic assessment of soil health and soil quality is necessary to evaluate the degradation status and changing trends following different land use and smallholder management interventions (Lal and Stewart, 1995). Protection of soil health under intensive land use and fast economic development is a major challenge for sustainable resource use in the developing world (Doran et al., 1996b). Soil have an inherent quality as related to their physical, chemical, and biological properties within the constraints set by climate and ecosystems, the ultimate determinant of soil quality and health is the land manager. As such, the assessment of soil quality or health, and direction of change with time, is the primary indicator of sustainable management. To evaluate sustainability of agricultural practices, assessment of soil health using various indicators of soil health is needed.

In the present scenario of vegetable cultivation under protected conditions in Himachal Pradesh, soil health degradation is emerging as a potential threat due to intensive cultivation and injudicious use of fertilizers through fertigation. The continuous cropping without application of adequate quantity of nutrients, imbalanced fertilization or without addition of organics has led to a loss in soil health. This condition has led to soils becoming sick in polyhouses with elapse of time. Therefore, sustainability of intensive agriculture system is intimately linked to maintenance or enhancement of soil health. In this context the present investigation was carried out to study the impact of intensive cultivation on soil health under polyhouse condition in mid hill zone of Himachal Pradesh.

\section{Materials and Methods}

Site description and soil sampling : The study was carried out in three districts (Solan, Mandi and Sirmour) of Himachal Pradesh (Fig. 1) located between $30^{\circ} 05^{\prime} 50^{\prime \prime}$ to $32^{\circ} 15^{\prime} 30^{\prime \prime} \mathrm{N}$ latitude and 76 ${ }^{\circ} 37^{\prime} 22^{\prime \prime}$ to $77^{\circ} 49^{\prime} 40^{\prime \prime} E$ longitude and altitude ranging from 300$3650 \mathrm{~m}$ above mean sea level. The climate of the studied area was sub-humid sub-tropical to wet temperate and received 1000

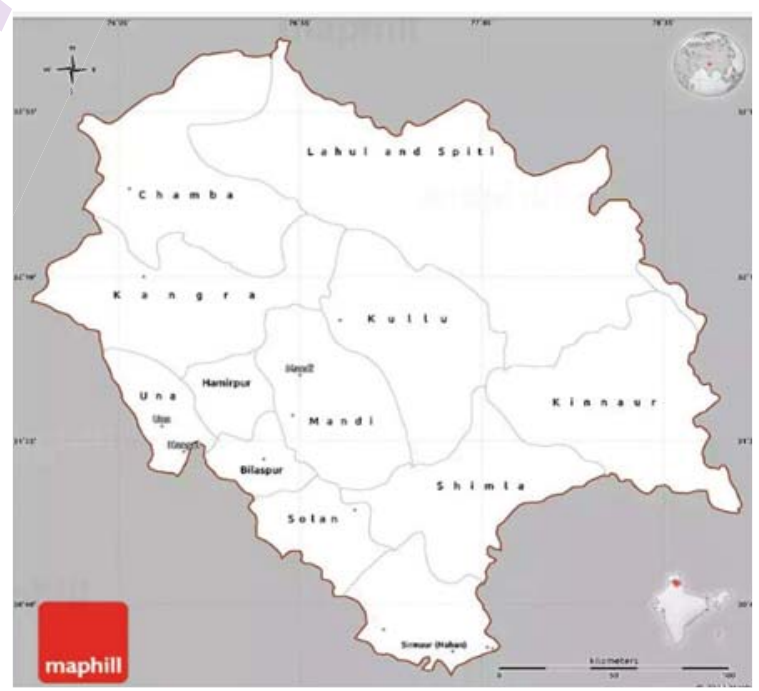

Fig. 1 : Map showing study area (Mandi, Solan and Sirmour) in Himachal Pradesh 
to $3900 \mathrm{~mm}$ annual rainfall with mean annual temperature $15^{\circ}$ to $20^{\circ} \mathrm{C}$. A preliminary survey of study area was conducted in order to select and collect basic information on the soil, nutrient management, cropping pattern and other cultural practices being followed in the polyhouses. Capsicum was the predominant vegetable crop in most of the polyhouses. Ten polyhouses were selected from each district and three composite soil samples ( 0 to $20 \mathrm{~cm}$ ) from each poly house were collected along with samples from adjacent open fields. The collected soil samples were air dried and then ground to pass through $2 \mathrm{~mm}$ sieve.

Soil analysis : Soil bulk density was determined by gravimetric method using undisturbed soil cores, while porosity was determined from bulk density and particle density. Soil pH and EC were determined by using 1:2 soil water suspension method (Jackson, 1973); organic carbon by wet digestion method (Walkley and Black,1934); CEC by sodium and ammonium acetate centrifugation method (Bower et al., 1952); bicarbonate and chlorides by rapid titration method (Reitemeier,1943); available nitrogen using alkaline potassium permanganate method (Subbiah and Asija, 1956); available phosphorous by Olsen's method (Olsen et al., 1954); available K, exchangeable $\mathrm{Ca}$ and $\mathrm{Mg}$ were determined by using neutral ammonium acetate and content was determined by aspirating the extract in to flame photometer (Jackson, 1973). The available sulphur in soils was extracted with $0.15 \% \mathrm{CaCl}_{2}$ solution as described by William and Steinbergs (1959); and DTPA extractable $\mathrm{Zn}, \mathrm{Fe}, \mathrm{Mn}$ and $\mathrm{Cu}$ in soil were estimated as per the standard method given by Lindsay and Norvell (1978). Fresh soil samples collected were immediately used for estimating biological properties. Soil microbial biomass carbon in soil was estimated by fumigation extraction method (Vance et al., 1987).

A total of 19 indicators were considered for soil health assessment. Soil Health Index (SHI) was calculated following the procedure outlined by Amacher et al. (2007). The rationale for the threshold level was selected on the basis of "more is better" or "less is better". The individual index values for all the soil properties were measured and were summed up to obtain the soil health index.

\section{Total SHI $=\Sigma$ individual soil property index values}

The maximum value of total SHI was 32 and related to 19 soil properties measured. SHI was then expressed as percentage of maximum possible value of total $\mathrm{SHI}$ for the soil properties that were estimated:

SHI $(\%)=($ total SHI $/$ maximum possible total SHI for properties measured) $\times 100$

The soil health of poly house and open condition were categorized following the rating given by Gugino et al. (2009).

Statistical analysis : The data recorded for different soil properties were analysed statistically by two way ANOVA and student t-test outlined by Gomez and Gomez (1984).

\section{Results and Discussion}

The average value of soil health parameters varied in polyhouse and open conditions of different district of the study area (Table 1). Bulk density under polyhouse condition (1.18 $\mathrm{Mgm}^{-3}$ )

Table 1: Mean of soil health parameters in polyhouses and open condition of different districts of Himachal Prdaesh

\begin{tabular}{|c|c|c|c|}
\hline \multirow[t]{2}{*}{ Soil indicators } & \multicolumn{2}{|c|}{ Condition } & \multirow[t]{2}{*}{$\mathrm{CD}_{0.05}$} \\
\hline & Polyhouse & Open condition & \\
\hline $\mathrm{BD}\left(\mathrm{mg} \mathrm{m}^{-3}\right)$ & $1.18^{\mathrm{b}}$ & $1.25^{\mathrm{a}}$ & 0.04 \\
\hline Porosity (\%) & $45.86^{\mathrm{a}}$ & $42.20^{b}$ & 1.59 \\
\hline $\mathrm{Cl}^{-}\left(\mathrm{cmol}\left(\mathrm{p}^{+}\right) \mathrm{kg}^{-1}\right)$ & $0.05^{\mathrm{a}}$ & $0.04^{\mathrm{a}}$ & NS \\
\hline $\mathrm{HCO}^{-3}\left(\mathrm{cmol}\left(\mathrm{p}^{+}\right) \mathrm{kg}^{-1}\right)$ & $1.65^{\mathrm{a}}$ & $1.06^{\mathrm{b}}$ & 0.09 \\
\hline $\operatorname{CEC}\left(\mathrm{cmol}\left(\mathrm{p}^{+}\right) \mathrm{kg}^{-1}\right)$ & $14.97^{\mathrm{a}}$ & $14.21^{\mathrm{b}}$ & 0.19 \\
\hline $\mathrm{pH}$ & $6.8^{\mathrm{a}}$ & $6.7^{\mathrm{b}}$ & 0.10 \\
\hline $\mathrm{EC}\left(\mathrm{dS} \mathrm{m}^{-1}\right)$ & $0.56^{\mathrm{a}}$ & $0.23^{b}$ & 0.10 \\
\hline $\mathrm{OC}(\%)$ & $1.76^{\mathrm{a}}$ & $1.37^{\mathrm{b}}$ & 0.13 \\
\hline$N\left(\mathrm{kgha}^{-1}\right)$ & $320.81^{a}$ & $287.64^{\mathrm{b}}$ & 11.28 \\
\hline$P\left(\mathrm{kgha}^{-1}\right)$ & $82.94^{\mathrm{a}}$ & $55.43^{\mathrm{b}}$ & 5.78 \\
\hline $\mathrm{K}\left(\mathrm{kgha}^{-1}\right)$ & $502.00^{\mathrm{a}}$ & $444.17^{\mathrm{b}}$ & 29.00 \\
\hline $\mathrm{Ca}\left(\mathrm{cmol}\left(\mathrm{p}^{+}\right) \mathrm{kg}^{-1}\right)$ & $11.43^{\mathrm{a}}$ & $10.31^{\mathrm{b}}$ & 0.39 \\
\hline $\mathrm{Mg}\left(\mathrm{cmol}\left(\mathrm{p}^{+}\right) \mathrm{kg}^{-1}\right)$ & $0.43^{\mathrm{a}}$ & $0.41^{\mathrm{b}}$ & 0.01 \\
\hline $\mathrm{SO}^{4}-\mathrm{S}\left(\mathrm{mg} \mathrm{kg}^{-1}\right)$ & $96.91^{\mathrm{a}}$ & $39.04^{b}$ & 13.95 \\
\hline $\mathrm{Zn}\left(\mathrm{mg} \mathrm{kg}^{-1}\right)$ & $2.99^{\mathrm{a}}$ & $2.31^{b}$ & 0.29 \\
\hline $\mathrm{Fe}\left(\mathrm{mg} \mathrm{kg}^{-1}\right)$ & $24.97^{\mathrm{a}}$ & $27.19^{a}$ & NS \\
\hline $\mathrm{Cu}\left(\mathrm{mg} \mathrm{kg}^{-1}\right)$ & $4.32^{\mathrm{a}}$ & $3.62^{\mathrm{a}}$ & NS \\
\hline $\mathrm{Mn}\left(\mathrm{mg} \mathrm{kg}^{-1}\right)$ & $6.55^{\mathrm{a}}$ & $7.71^{\mathrm{a}}$ & NS \\
\hline $\operatorname{SMC}\left(\mu g g^{-1}\right)$ & $459.89^{\mathrm{a}}$ & $377.13^{b}$ & 62.20 \\
\hline
\end{tabular}


Table 2: Contribution of different parameters in soil health status in different districts of Himachal Pradesh

\begin{tabular}{|c|c|c|c|c|c|c|c|c|c|}
\hline \multirow[t]{2}{*}{ Soil indicators } & \multicolumn{3}{|c|}{ Mandi } & \multicolumn{3}{|c|}{ Solan } & \multicolumn{3}{|c|}{ Sirmour } \\
\hline & $\begin{array}{l}\text { Poly } \\
\text { (mean) }\end{array}$ & $\begin{array}{l}\text { Open } \\
\text { (mean) }\end{array}$ & $\mathrm{t}$-cal & $\begin{array}{l}\text { Poly } \\
\text { (mean) }\end{array}$ & $\begin{array}{l}\text { Open } \\
\text { (mean) }\end{array}$ & t-cal & $\begin{array}{l}\text { Poly } \\
\text { (mean) }\end{array}$ & $\begin{array}{l}\text { Open } \\
\text { (mean) }\end{array}$ & t-cal \\
\hline $\mathrm{BD}\left(\mathrm{mg} \mathrm{m}^{-3}\right)$ & 1.14 & 1.25 & -1.58 & 1.16 & 1.15 & 0.14 & 1.24 & 1.34 & -1.35 \\
\hline Porosity (\%) & 46.72 & 40.45 & 2.06 & 47.83 & 47.45 & 0.09 & 43.04 & 38.69 & 1.44 \\
\hline Bicarbonate $\left(\mathrm{cmol}\left(\mathrm{p}^{+}\right) \mathrm{kg}^{-1}\right)$ & 2.42 & 1.60 & 2.53 & 1.01 & 1.03 & -0.07 & 0.99 & 1.06 & -0.23 \\
\hline Chloride $\left(\mathrm{cmol}\left(\mathrm{p}^{+}\right) \mathrm{kg}^{-1}\right)$ & 0.06 & 0.07 & -0.38 & 0.02 & 0.03 & 0.06 & 0.06 & 0.03 & 2.40 \\
\hline pH & 6.98 & 6.80 & 1.00 & 7.00 & 6.71 & 1.25 & 6.55 & 6.61 & -0.22 \\
\hline $\mathrm{EC}\left(\mathrm{dS} \mathrm{m}^{-1}\right)$ & 0.51 & 0.19 & 4.24 & 0.63 & 0.24 & 2.23 & 0.55 & 0.24 & 3.52 \\
\hline $\mathrm{OC}(\%)$ & 1.78 & 1.85 & -0.26 & 1.85 & 1.53 & 1.17 & 1.66 & 1.14 & 2.58 \\
\hline$N\left(\mathrm{kgha}^{-1}\right)$ & 277.71 & 229.24 & 1.71 & 319.44 & 294.09 & 0.89 & 365.27 & 339.58 & 1.01 \\
\hline$P\left(\mathrm{kgha}^{-1}\right)$ & 52.59 & 28.22 & 3.97 & 92.74 & 66.32 & 2.27 & 103.49 & 71.73 & 2.12 \\
\hline$K\left(\mathrm{kgha}^{-1}\right)$ & 506.24 & 434.27 & 0.75 & 505.40 & 484.72 & 0.26 & 494.37 & 413.50 & 0.96 \\
\hline $\mathrm{Ca}\left(\mathrm{cmol}\left(\mathrm{p}^{+}\right) \mathrm{kg}^{-1}\right)$ & 11.78 & 10.56 & 0.98 & 11.73 & 10.89 & 0.75 & 10.77 & 9.47 & 1.48 \\
\hline $\mathrm{Mg}\left(\mathrm{cmol}\left(\mathrm{p}^{+}\right) \mathrm{kg}^{-1}\right)$ & 0.48 & 0.44 & 1.98 & 0.41 & 0.40 & 0.13 & 0.40 & 0.38 & 0.79 \\
\hline $\mathrm{S}\left(\mathrm{mg} \mathrm{kg}^{-1}\right)$ & 85.08 & 39.85 & 2.97 & 101.58 & 42.70 & 2.55 & 104.06 & 34.58 & 2.87 \\
\hline $\mathrm{Zn}\left(\mathrm{mg} \mathrm{kg}^{-1}\right)$ & 3.46 & 3.25 & 0.41 & 3.13 & 3.31 & -0.48 & 2.39 & 2.29 & 0.18 \\
\hline $\mathrm{Fe}\left(\mathrm{mg} \mathrm{kg}^{-1}\right)$ & 25.89 & 28.47 & -0.63 & 23.51 & 26.82 & -1.01 & 25.51 & 26.27 & -0.10 \\
\hline $\mathrm{Mn}\left(\mathrm{mg} \mathrm{kg}^{-1}\right)$ & 8.10 & 8.46 & -0.15 & 4.28 & 6.25 & -2.32 & 7.26 & 8.41 & -0.24 \\
\hline $\mathrm{Cu}\left(\mathrm{mg} \mathrm{kg}^{-1}\right)$ & 2.64 & 2.16 & 0.58 & 7.30 & 5.90 & 0.63 & 3.02 & 2.79 & 0.24 \\
\hline MB $\left(\mu g g^{-1}\right)$ & 472.61 & 416.03 & 0.79 & 501.49 & 378.94 & 2.12 & 405.57 & 336.43 & 1.71 \\
\hline $\operatorname{CEC}\left(\mathrm{cmol}\left(\mathrm{p}^{+}\right) \mathrm{kg}^{-1}\right)$ & 14.61 & 14.18 & 0.65 & 16.18 & 15.51 & 1.31 & 14.12 & 12.93 & 1.87 \\
\hline
\end{tabular}

$\mathrm{t}$ - Table value $(0.05)=2.100922$, $\mathrm{t}$ - Table value $(0.01)=2.87844$

was significantly lower than the open condition (1.25 $\left.\mathrm{Mgm}^{-3}\right)$. Regular application of organic manure in polyhouses decreased the bulk density. Hence, the soils in polyhouse condition were less compact and good for crop production as there was better aggregation, high porosity and improved soil structure (Kharche et al., 2013). Organic matter had strong negative correlation ( $r=-$ 0.87 ) with bulk density (Ahad et al., 2015). The porosity ranged from 40.86 to $47.65 \%$ in the study area. Higher porosity percent was observed under polyhouse conditions ( $45.86 \%$ ) as compared to open condition (42.20\%). Higher percent porosity observed in the polyhouses may be due to decreased bulk density (Ezeaku, 2015).

The normal range of chloride content was encountered for most of the crops. Irrespective of districts, statistically non significant higher chloride content was noticed under polyhouses $\left(0.05 \mathrm{cmol}\left(p^{+}\right) \mathrm{kg}^{-1}\right)$ as compared to open conditions $(0.04 \mathrm{cmol}$ $\left.(p+) \mathrm{kg}^{-1}\right)$. Regarding bicarbonate the polyhouse soils recorded comparatively high bicarbonate content $\left(1.65 \mathrm{cmol}(\mathrm{p}+) \mathrm{kg}^{-1}\right)$ than open condition $\left(1.06 \mathrm{cmol}(\mathrm{p}+) \mathrm{kg}^{-1}\right)$. This might be ascribed to more addition of fertilizers in polyhouse conditions. Yao et al. (2007) reported that polyhouse soils are partially salted as the ions mostly from fertilizer auxiliary component or fertilizer transformation component besides some original deposition accumulate in the soil. So, the formation of soil secondary salts in polyhouse cultivation had a close relationship with improper fertilization or employing too much fertilizer. The soil under polyhouse conditions registered higher values of CEC $(14.97 \mathrm{cmol}$ $\left.(\mathrm{p}+) \mathrm{kg}^{-1}\right)$ than open conditions $\left(14.21 \mathrm{cmol}\left(\mathrm{p}^{+}\right) \mathrm{kg}^{-1}\right)$. The farmers were using comparatively more quantity of FYM in polyhouse condition which is attributed to high content of soil organic carbon. Since CEC is mainly contributed by organic matter and have significant and positive correlation, it is quite obvious that polyhouse soils had higher CEC as compared to open condition (Kumar et al., 2011). The chemical properties of soil revealed that it was slightly acidic to neutral in reaction. This might be attributed to the buffering effect of high organic matter. However, soils under polyhouses recorded higher $\mathrm{pH}$ (6.84) than open condition (6.71) which could be due to the continuous application of compost, animal dung and manure, which might have worked as liming. The

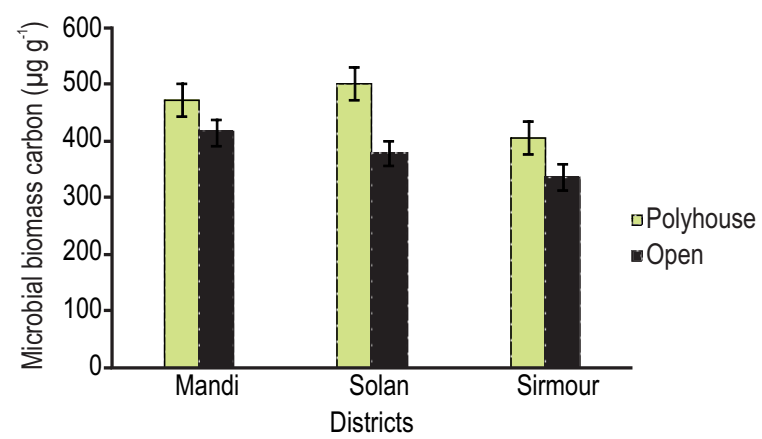

Fig. 2 : Microbial biomass carbon $\left(\mu \mathrm{g} \mathrm{g}^{-1}\right)$ under polyhouse and open conditions of three districts of Himachal Pradesh 

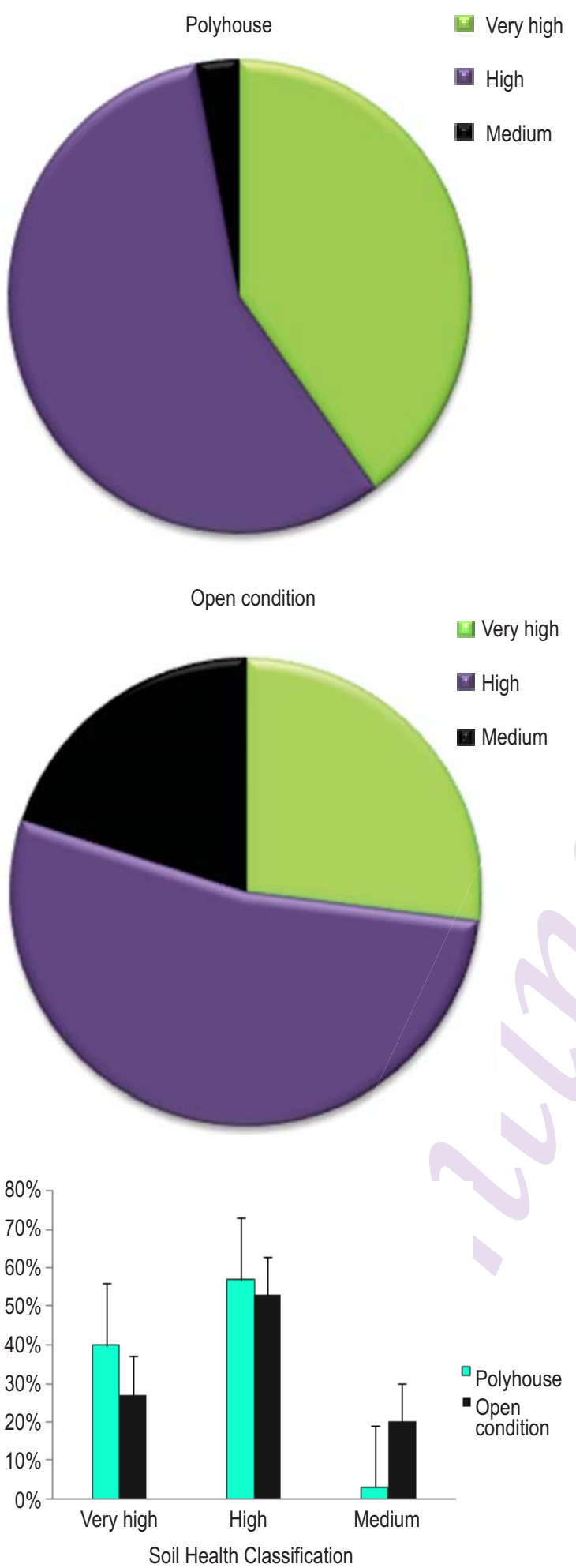

Fig. 3 : Distribution of soil health index (\%) under polyhouse and open condition of three districts of Himachal Pradesh

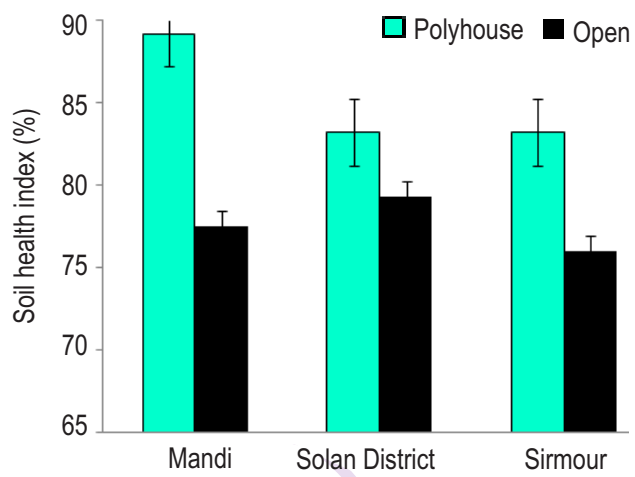

Fig. 4 : Soil Health index (\%) under polyhouse and open condition of different districts of Himachal Pradesh

presence of slightly acidic to neutral soil reaction in polyhouse and open conditions of different sites was favourable for availability of most of the nutrient elements and plant growth. In general, EC values ranged from 0.23 to $0.56 \mathrm{dS} \mathrm{m}^{-1}$. In comparison, EC was significantly higher with $0.56 \mathrm{dS} \mathrm{m}^{-1}$ in soils under polyhouse condition than in open fields. Shi et al. (2009) suggested that leaching of nitrogen under open condition is one component counteracting secondary salinization than polyhouse condition. Another relevant factor which favours salinization is temperature. Higher temperature increases evapotranspiration and amplify the salt accumulation on the top soil. The third relevant factor is the fertilization level, which is two to three times higher in polyhouse condition than the open field (Cao et al., 2004). The organic carbon is the key component of soils health because of its influence on physical, chemical and soil biota. Organic carbon content varied from 1.37 to $1.76 \%$. Therefore, soils were characterized by high organic carbon content mainly on the account of sub-humid sub-tropical to wet temperate climate which resulted in slow decomposition and mineralization of organic matter content. The organic carbon content was high in polyhouse condition (1.76\%) as compared to open condition (1.37\%). This might be due to the management practices and more addition of FYM under protective cultivation systems. Significantly more available nitrogen was recorded under polyhouse condition (320.81 kg ha') than those of adjacent fields (open condition) $287.64 \mathrm{~kg} \mathrm{ha}^{-1}$. The favourable soil conditions and addition of higher input of fertilizer $\mathrm{N}$ and organic manures in intensive vegetable production systems leading to build up of higher available $\mathrm{N}$ in polyhouse condition. The available $\mathrm{P}$ content varied between 82.94 and $55.43 \mathrm{~kg} \mathrm{ha}^{-1}$ in polyhouse and open conditions, respectively. The appreciable build-up of available $P$ might be due to the influence of organic matter in increasing the labile phosphorus in soil through complexing of cations which are responsible for fixation of phosphorus (Karche et al., 2013). The available potassium was found to be higher under polyhouse condition ( $502.00 \mathrm{~kg} \mathrm{ha}^{-1}$ ) as compared to open condition (444.17 $\left.\mathrm{kg} \mathrm{ha}{ }^{-1}\right)$. The higher content of available potassium under 
integrated use of manures and fertilizers in polyhouses might be due to greater capacity of organic colloids to hold ions on the exchange sites (Sheeba and Chellamuthu, 1999), reduction of potassium fixation and release of more potassium due to interaction of organic matter with clay, besides direct potassium addition in the available potassium pool of the soil. The exchangeable calcium, magnesium and sulphate was found more under polyhouse condition i.e. $11.43 \mathrm{cmol}(\mathrm{p}+) \mathrm{kg}^{-1}(\mathrm{Ca}), 0.43 \mathrm{cmol}$ $(\mathrm{p}+) \mathrm{kg}^{-1}(\mathrm{Mg})$ and $96.91 \mathrm{mg} \mathrm{kg}^{-1}\left(\mathrm{SO}^{4} \mathrm{~S}\right)$ than open conditions $10.31 \mathrm{cmol}^{+} \mathrm{p}^{+} \mathrm{kg}^{-1}, 0.41 \mathrm{cmol}\left(\mathrm{p}^{+}\right) \mathrm{kg}^{-1}$ and $39.04 \mathrm{mg} \mathrm{kg}^{-1}$, respectively. High content under polyhouse conditions might be attributed to regular addition of mix / complex fertilizers. There was more use of sulphur fertilizers (MgSO4), insecticides, pesticides (diethane and microsol) and accumulation of organic matter which resulted in high content of available sulphur. Further, high content of sulphate ions in soils of Himachal Pradesh might also be due to the presence of gypsiferrous and ferruginous nature of parent material.

Significantly higher content of zinc $\left(2.99 \mathrm{mg} \mathrm{kg}^{-1}\right)$ was observed under polyhouse condition as compared to open (2.31 $\left.\mathrm{mg} \mathrm{kg}^{-1}\right)$. This might be due to the application of $\mathrm{ZnSO}_{4}$ and blitoxin for vegetable production. Use of FYM along with chemical fertilizer was found useful in maintaining available micronutrient status of soil. Addition of organic materials might have enhanced the microbial activity in soil, and consequently the release of complex organic substances like chelating agents could have prevented micronutrients from precipitation, fixation, oxidation and leaching apart from addition of these nutrients through organic source. So application of FYM significantly enhanced the DTPA extractable Zinc (Sharma et al., 2015).

Variation in the microbial biomass under different conditions ranged from 377.13 to $459.57 \mu \mathrm{g} \mathrm{g}^{-1}$ (Fig. 2). The value of microbial biomass was significantly higher in polyhouse condition as compared to open condition. More microbial biomass under polyhouse condition might be attributed to organic carbon, which provides more substrate and favorable atmosphere for the development of microbes. The protected cultivation had both negative and positive effect on the microbial communities. On one hand, high organic matter increased the soil microorganism but sometimes overuse of nitrogen, phosphatic fertilizers and pesticides might reduce microbial population. The positive effect of soil organic matter on microbial biomass might be more pronounced in the present study. Biswas et al. (2007) also reported that microbial biomass and soil organic carbon responded positively to the application of organics (FYM) in conjunction with inorganic to the soil. In addition, an increase in soil carbon content indicates higher microbial biomass (Sparling et al., 2003).

An index of soil health was developed that integrates physical, chemical and biological properties of soil into a single number that serves as the soil's "vital sign" of overall soil health/ quality. The data revealed that polyhouse soils in the mid hill zone of Himachal Pradesh were rated as 40,57 and $3 \%$ as very high, high and medium health level, respectively. Contrary to this, 27 , 53 and $20 \%$ soils in open conditions fell in very high, high and medium soil health conditions, respectively (Fig. 3). It can be summarized that health status of soil under polyhouse condition was at higher level as compared to corresponding open conditions in each district of the Himachal Pradesh (Fig. 4). This may be attributed to balanced and regular application of nutrients combined with farmyard manure might increase soil nutrients and soil organic carbon content.

The contribution of most indicators to soil health had no significant difference in polyhouse and open condition. The $\mathrm{pH}, \mathrm{N}$, $\mathrm{K}, \mathrm{Ca}, \mathrm{Mg}$, micronutrients and bicarbonates had less influence on soil health; while EC, phosphate, organic carbon, porosity, chloride, sulphur and microbial biomass greatly influenced the soil health (Table 2). Juan (2013), while studying quantitative assessment of soil health under different planting patterns and soil type revealed $\mathrm{pH}, \mathrm{Ca}$ and $\mathrm{S}$ exerted less influence on soil health, while organic carbon, phosphate fertilizers under a green house condition had limited the development of soil health.

The foregoing results suggested that relatively more healthy and productive soil was observed in the polyhouse conditions as compared to open conditions. The majority of polyhouse soils in mid hill zone of Himachal Pradesh had high soil health level which accounted for $57 \%$ of the surveyed samples, followed by very high (40\%) and medium soil health (3\%). Soil health was found to be affected by the management practices adopted by the farmer and the extent of fertilizer use over a period of time. In addition, further investigations are necessary to see the change in the soil health index with change in the age of polyhouses.

\section{Acknowledgments}

Authors would like to thank Dr. J.N. Raina, Dr. R.S. Spehia, Dr. Uday Sharma of the Department of Soil Science and Water Management and Dr. R.K. Gupta of the Department of Basic Science of Dr. Y.S. Parmar University of Horticulture and Forestry, Nauni, Solan, Himachal Pradesh, India.

\section{References}

Ahad, T., T.A. Kanth and S. Nabi: Soil bulk density as related to texture, organic matter content and porosity in kandi soils of district Kupwara (Kashmir Valley), India. Int. J. Sci. Res., 4, 198-200 (2015).

Amacher, M., C. O'Neil, K.P. Perry and H. Charles: S oil vital signs: Anew Soil Quality Index (SQI) for assessing forest soil health. Res. Pap. RMRS-RP-65WWW. Fort Collins,CO: U.S. Department of Agriculture, Forest Service, Rocky Mountain Research Station. p. 12 (2007).

Biswas, H., R.K. Rattan and A.K. Singh: Effect of soil manipulation and resource management on carbon and nitrogen turnover under rice-wheat cropping system. J. Ind. Soc. Soil. Sci., 55, 276-284 (2007). 
Bower, C.A., F.B. Gschwend, R.F. Reitemeier and M. Fireman: Exchangeable cation analysis of saline and alkali soils. Soil Sci., 73, 251-261 (1952).

Cao, Z.H., J.F. Huang, C.S. Zhang and A.F. Li: Soil quality evolution after land use change from paddy soil to vegetable land. Environ. Geochem. Hlth., 26, 97-103 (2004).

Doran, J.W. and A.J. Jones: Methods for assessing soil quality. Soil Science Society of America Special Publication. vol. 49, Soil Science Society of America, Madison, Wisconsin (1996a).

Doran, J.W. and M.R. Zeiss: Soil health and sustainability: Managing the biotic component of soil quality. App. Soil Eco., 15, 3-11 (2000).

Doran, J.W., M. Sarrantonio and M. Liebig: Soil health and sustainability. In: Advances in Agronomy (Ed. D.L. Sparks). Academic Press, San Diego, 56, pp. 1-54 (1996b)

Ezeaky, P.: Evaluation of agro-ecological approach to soil quality assessment for sustainable land use and management systems. Sci. Res. Essays, 10, 501-512 (2015).

Gomez, K.A. and A.A. Gomez: Statistical procedure for agricultural research $2^{\text {nd }}$ Edn., John Wiley and Sons, Inc., New York, USA. p. 680 (1984).

Gugino, B.K., O.J. Idowu, R.R. Schindelbeck, H.M. VanEs, D.W. Wolfe, B.N. Moebius-Clune, J.E. Thies and G.S. Abawi: Cornell Soil Health Assessment Training Manual. $2^{\text {nd }}$ Edn., Cornell University, Geneva, NY (2009).

Jackson, M.L.: Soil Chemical Analysis. Prentice Hall of India Pvt. Ltd., New Delhi (1973).

Juan, B.C., L. Chen, W.J. Zhen and D. Zhou: Quantitative assessment of soil health under different planting patterns and soil types. Pedosphere, 23, 194-204 (2013).

Karlen, D.L., S.S. Andrews and J.W. Doran: Soil quality: Current concepts and applications. Advan. Agron., 74, 1-40 (2001).

Kharche, V.K., S.R. Patil, A.A. Kulkarni, V.S. Patil and R.N. Katkar: Longterm integrated nutrient management for enhancing soil quality and crop productivity under intensive cropping system. J. Indian Soc. Soil Sci., 61, 323-332 (2013).

Kumar, M., S.K. Singh, P. Raina and B.K. Sharma: Status of available major and micronutrients in arid soils of Churu district of western Rajasthan. J. Indian Soc. Soil Sci., 59, 188-192 (2011).

Lal, R. and B.A. Stewart: Soil Management: Experimental Basis for Sustainability and Environmental Quality. Advances. In: Soil
Science. CRC Press, Boca Raton, Florida (1995).

Lindsay, W.H. and W.A. Norvell: Development of DTPA soil test for Zn, Fe, Mn and Cu. Soil Sci. Soc. Am. J., 42, 420-428 (1978).

Mandal, K.M., K. Ramachandran, K.L. Sharma, B Satyam, K. Venkanna, M.U. Bhanu, M. Mandal and R.N. Masane:Assessing soil quality in a semiarid tropical watershed using geographical information system. Soil Sci. Sci. Am. J., 75, 1144-1160 (2011).

Olsen, S.R., C.V. Cole, F.S. Watanable and L.A. Dean: Estimation of available phosphorous in soil by extraction with sodium bicarbonate. USDA Circular, 939, 1-19 (1954).

Reitemeier, R.F.: Semimicro analysis of saline soil solution. Ind. Eng. Chem., Anal. Ed., 15, 393-402 (1943).

Sharma, V.K., R.N. Pandey and B.M. Sharma: Studies on long term impact of STCR based integrated fertilizer use on pearl millet (Pennisetum glaucum) - wheat (Triticum aestivum) cropping system in semi arid condition of India. J. Environ. Biol., 36, 241-247 (2015).

Sheeba, S. and S. Chellamuthu: Long-term influence of organic and inorganic fertilization on the macronutrient status of inceptisols. J. Indian Soc. Soil Sci., 47, 803-804 (1999).

Shi, Y.C., Z.Y. Hu, S. Haneklaus, W.G. Long, X. Xu, Y.W. Zhao, T. Lin and E. Schnug: Suitability of soil electrical conductivity as an indicator of soil nitrate status in relation to vegetable cultivation practices in the Yangtze river delta of Chiana. Agri. For. Res., 2, 151-158(2009).

Sparling, G., R.L. Parfitt, A.E. Hewitt and L.A. Schipper: Three approaches to define desired soil quality matter content. J. Environ Qual., 32, 760-766 (2003).

Subbiah, B.V. and G.L. Asija: Rapid method for estimation of available nitrogen in soils. Curr. Sci., 25, 259-260 (1956).

Vance, E.D., P.C. Brookes and D.S. Jenkinson: An extraction method for measuring soil microbial biomass carbon. Soil Bio. Biochem., 19, 703-707 (1987).

Walkley, A. and I.A. Black: Examination of the method for determining soil organic matter and a proposed modification of the chromic acid titration method. Soil Sci., 37, 29-38 (1934).

Williams, C.H. and S. Steinbergs: Soil sulphur fractions as chemical indices of available sulphur in some Australian soils. J. Agri. Res. 10, 340-352 (1959).

Yao, C.X., Z.L. Chen and S.Y. Xu: Soil salinity content of greenhouse in Shanghai suburb. Huan Jing Ke Xue, 28, 1372-1376 (2007). 